\title{
PELATIHAN PENERAPAN APLIKASI AUGMENTED REALITY PENGENALAN BAHASA ISYARAT DI SLB NEGERI LURAGUNG KABUPATEN KUNINGAN PROVINSI JAWA BARAT
}

\author{
Tito Sugiharto, Gentur Priguna S, dan Ardianto \\ Program Studi Teknik Informatika, Fakultas Ilmu Komputer, Universitas Kuningan, Indonesia \\ E-mail: tito@uniku.ac.id
}

\begin{abstract}
Community Service Activities/ Kegiatan Pengabdian Kepada Masyarakat (PKM) with the theme "Training on Application of Augmented Reality Application for Sign Language Introduction in SLB Negeri Luragung, Cirahayu Village, Luragung Subdistrict, West Java Province" has a target of Teachers and Students in schools. The problems faced by partner institutions in community service activities include: the learning process of Sign Language in SLB Negeri Luragung still uses book media as the main media in learning. Besides learning media provided at SLB Negeri Luragung also by reading utterances through lip movements combined with cued speech. In addition, the problem faced by teachers in schools for deaf students is the development of language in its function as a means of communication, both verbally and signaling. Language development and speech go together with hearing acuity. Due to limited hearing, deaf students do not occur in the process of imitation of sound, imitation process is only limited to visual imitation. Therefore we need an alternative media for learning that can help the process of visual imitation. The absence of additional alternative learning media used in SLB Negeri Luragung that can help teachers and students in helping students communicate and learn easily becomes a special goal in community service activities. Community service aims to train and implement Augmented Reality Technology as an innovation and development of sign language learning media applications in SLB Negeri Luragung. Deaf students in SLB Negeri Luragung are expected to be able to more easily and quickly understand the sign language learning process with the application of learning based on Augmented Reality.
\end{abstract}

Keywords: Augmented Reality, Deaf, Learning, SLB Negeri Luragung, Sign Language

\begin{abstract}
Abstrak
Kegiatan Pengabdian Kepada Masyarakat (PKM) dengan tema "Pelatihan Penerapan Aplikasi Augmented Reality Pengenalan Bahasa Isyarat di SLB Negeri Luragung Desa Cirahayu Kecamatan Luragung Provinsi Jawa Barat" memiliki target Guru dan Siswa di sekolah. Permasalahan yang dihadapai oleh lembaga mitra dalam kegiatan pengabdian kepada masyarakat ini diantaranya adalah: proses pembelajaran Bahasa Isyarat di SLB Negeri Luragung masih menggunakan media buku sebagai media utama dalam pembelajaran. Selain itu media pembelajaran yang diberikan di SLB Negeri Luragung juga dengan cara membaca ujaran melalui gerakan bibir yang digabung dengan cued speech. Selain itu, Permasalahan yang dihadapi oleh Guru di sekolah untuk siswa tuna rungu adalah pengembangan kebahasaan dalam fungsinya sebagai alat berkomunikasi, baik secara lisan maupun isyarat. Perkembangan bahasa dan bicara berakitan dengan ketajaman pendengaran. Akibat terbatasnya pendengaran, siswa tuna rungu tidak terjadi proses peniruan suara, proses peniruan hanya terbatas pada peniruan visual. Oleh sebab itu diperlukan sebuah media alternative untuk pembelajaran yang dapat membantu proses peniruan visual. Belum adanya media pembelajaran alternative tambahan yang digunakan di SLB Negeri Luragung yang dapat membantu guru dan siswa dalam membantu siswa berkomunikasi dan belajar dengan mudah menjadi tujuan khusus dalam kegiatan pengabdian kepada masyarakat ini. Pengabdian kepada masyarakat ini bertujuan untuk melatih dan menerapkan Teknologi Augmented Reality sebagai sebuah inovasi dan pengembangan aplikasi media pembelajaran bahasa isyarat di SLB Negeri Luragung. Siswa Tuna rungu di SLB Negeri Luragung diharapkan dapat lebih mudah dan cepat memahami dalam proses pembelajaran bahasa isyarat dengan adanya aplikasi pembelajaran berbasis Augmented Reality.
\end{abstract}

Kata Kunci : Augmented Reality, Tunarungu, Pembelajaran, SLB Negeri Luragung, Bahasa Isyarat 


\section{PENDAHULUAN}

Sekolah Luar Biasa Negeri Luragung adalah sekolah luar biasa yang berada di daerah Kabupaten Kuningan. Sekolah ini terletak di Desa Cirahayu Kecamatan Luragung Kabupaten Kuningan - Jawa Barat. Sekolah ini didirikan pada tanggal 20 Agustus tahun 2003. Sekolah yang berusia 16 tahun ini sudah terakreditasi A dan berstatus sebagai sekolah Negeri. Kegiatan sekolah di selenggarakan pada pagi hari sampai dengan siang hari seperti sekolah pada umumnya. Satuan pendidikan yang ada di sekolah ini adalah TKLB, SDLB, SMPLB dan SMALB.

Adapun Visi dan Misi dari sekolah ini adalah sebagai berikut :

Visi :

"Dengan Iman dan Taqwa SLB Negeri Luragung menjadi lembaga pendidikan khusus yang berkualitas dan mandiri melalui keterampilan berbasis life skill dan ICT pada tahun 2015 - 2020"

Misi :

1. Memberikan kesempatan belajar kepada anak - anak berkebutuhan khusus.

2. Membantu anak berkebutuhan khusus dalam mengatasi masalah kelainannya.

3. Meningkatkan kemampuan profesionalisme kinerja pendidikan dan tenaga kependidikan di SLB Negeri Luragung.

4. Meningkatkan sosialisasi dan penjaringan anak berkebutuhan khusus di Kecamatan Luragung Kabupaten Kuningan.

5. Memberikan motivasi kepada masyarakat agar menyadari pentingnya pendidikan anak berkebutuhan khusus.

6. Meningkatkan kerjasama dengan pihak lain baik individu, instansi pemerintah maupun swasta.

7. Menciptakan lingkungan sekolah yang kondusif bagi kelancaran proses pendidikan.

Belajar merupakan kegiatan berproses dan merupakan unsur yang sangat penting dalam setiap jenjang pendidikan. Dalam proses pendidikan, kegiatan belajar merupakan kegiatan yang paling cocok dan penting dalam keseluruhan proses pendidikan ${ }^{1}$. Proses pembelajaran Bahasa Isyarat di SLB Negeri Luragung masih menggunakan media buku sebagai media utama dalam pembelajaran. Selain itu media pembelajaran yang diberikan di SLB Negeri Luragung juga dengan cara membaca ujaran melalui gerakan bibir yang digabung dengan cued speech. Cued speech merupakan suatu gerakan tangan yang digunakan untuk bisa melengkapi gerakan pada bibir. SLB Negeri Luragung belum memiliki media pembelajaran Bahasa Isyarat berbasis digital, seperti media pembelajaran berbasis Augmented Reality. Tenaga pendidik merupakan sumberdaya yang harus dilindungi, sehingga tenaga pendidikan dalam mengabdi demi pendidikan yang berkualitas berjalan dengan nyaman dan $\operatorname{aman}^{2}$. Setiap tenaga pendidik tentu selalu mengalami permasalahan yang berbeda-beda.

Permasalahan yang dihadapi oleh Guru di sekolah untuk siswa tuna rungu adalah pengembangan kebahasaan dalam fungsinya sebagai alat berkomunikasi, baik secara lisan maupun isyarat. Perkembangan bahasa dan bicara berakitan dengan 
ketajaman pendengaran. Akibat terbatasnya pendengaran, siswa tuna rungu tidak terjadi proses peniruan suara, proses peniruan hanya terbatas pada peniruan visual. Oleh sebab itu diperlukan sebuah media alternative untuk pembelajaran yang dapat membantu proses peniruan visual.

Belum adanya media pembelajaran alternative tambahan yang digunakan di SLB Negeri Luragung yang dapat membantu guru dan siswa dalam membantu siswa berkomunikasi dan belajar dengan mudah menjadi tujuan khusus dalam kegiatan pengabdian kepada masyarakat ini. Pengabdian kepada masyarakat ini bertujuan untuk melatih dan menerapkan Teknologi Augmented Reality sebagai sebuah inovasi dan pengembangan aplikasi media pembelajaran bahasa isyarat di SLB Negeri Luragung. Siswa Tuna rungu di SLB Negeri Luragung diharapkan dapat lebih mudah dan cepat memahami dalam proses pembelajaran bahasa isyarat dengan adanya aplikasi pembelajaran berbasis Augmented Reality.

Penelitian mengenai augmented reality sudah banyak dilakukan.. Aisyah melakukan penelitian dengan judul "Aplikasi Multimedia Bahasa Isyarat Dasar Anak Tuna Rungu 6-9 Tahun”. Penelitian mereka bertujuan untuk menghasilkan sebuah media pembelajaran untuk anak tuna rungu menggunakan HTML 5, Javascript dan css. Media pembelajaran yang dibuat khusus untuk dijalankan di komputer saja, (Aisyah, Mutia., Husni Thamrin, Umi Fadlilah, 2013) ${ }^{3}$. Doni melakukan penelitian dengan judul "Perancangan Aplikasi Communication Board Berbasis Andoid Tablet Sebagai Media Pembelajaran dan Komunikasi Bagi Anak Tuna Rungu”. Hasil dari penelitian mereka menghasilkan sebuah aplikasi PankoTuli yang diimplementasikan menggunakan perangkat smartphone berbasis android dengan sistem operasi android versi 4.2.2 Jelly Beans. Hasil pengujian aplikasi PankoTuli memiliki tingkat kemudahan dalam penggunaannya $68.32 \%$ (Indras, Dhoni., Herman Tolle, Agi Putra, 2018) ${ }^{4}$. Margareta melakukan penelitian dengan judul "Rancang Bangun Aplikasi Pembelajaran Pengucapan Bagi Penderita Tuna Rungu Menggunakan Teknologi Kinect”. Hasil dari penelitian mereka adalah dihasilkannya sebuah aplikasi menggunakan Teknologi Kinect yang mampu mendeteksi gerak dan suara. Pendeteksian gerak dan suara digunakan untuk membuat sistem pembelajaran pengucapan (Hardiyanti, Margareta., Umi Laili, Abdul Munif, 2013) ${ }^{5}$.

Amanda melakukan penelitian dengan judul "Aplikasi Permainan Berbasis Android dalam Meningkatkan Kemampuan Kosakata Anak Tuna Rungu”. Hasil dari penelitian yang dilakukan adalah untuk menghasilkan media pembelajaran melalui aplikasi permainan berbasis android untuk anak tuna rungu kelas 1 yang layak digunakan untuk meningkatkan kemampuan kosakata. Hasil uji coba kelompok kecil memperoleh rata-rata pre-test 63,33 dan post-test 83,33.Berdasarkan hasil uji coba, terdapat kenaikan nilai sebelum dan sesudah menggunakan media (Qoyyimah, Amanda Dina, dan Eka Pramono, 2017) ${ }^{6}$.

Permasalahan Mitra, berdasarkan uraian di atas dapat dirumuskan sebagai berikut: 
1. Bagaimana menerapkan dan menggunakan aplikasi Augmented Reality Pengenalan Bahasa Isyarat pada smartphone dengan mudah dan menarik sebagai media pembelajaran tambahan?

2. Bagaimana meningkatkan pemahaman dalam penggunaan aplikasi Augmented Reality Pengenalan Bahasa Isyarat dalam proses pembelajaran di SLB Negeri Luragung? Pemahaman yang dimaksud meliputi:

a. Pemahaman instalasi aplikasi

b. Pemahaman penggunaan aplikasi

c. Pemahaman implementasi aplikasi

3. Bagaimana meningkatkan kemampuan dalam penggunaan aplikasi Augmented Reality Pengenalan Bahasa Isyarat dalam proses pembelajaran di SLB Negeri Luragung, kemampuan yang dimaksud meliputi:

a. Kemampuan instalasi aplikasi

b. Kemampuan penggunaan aplikasi

c. Kemampuan implementasi aplikasi

Justifikasi pengusul bersama mitra dalam kegiatan pengabdian kepada masyarakat ini adalah sebagai berikut:

1. Memberikan penyuluhan dan pelatihan mengenai penggunaan teknologi Augmented Reality dalam bentuk aplikasi Augmented Reality pengenalan bahasa isyarat;

2. Menerapkan dan mengimplementasikan produk hasil penelitian berupa aplikasi Augmented Reality pengenalan bahasa isyarat;

3. Demo aplikasi Augmented Reality pengenalan bahasa isyarat.

Solusi permasalahan yang ada pada Mitra dari program kegiatan Pengabdian kepada masyarakat ini adalah sebagai berikut:

1. Meningkatkan wawasan dan kemampuan tentang perkembangan ilmu pengetahuan dan teknologi informasi bagi pihak sekolah, guru, dan siswa.

2. Meningkatkan kemampuan dalam penggunaan media bahan ajar alternative atau bahan ajar tambahan berupa penerapan aplikasi Augmented Reality dalam pengenalan bahasa isyarat.

3. Memberikan stimulus untuk proses pembelajaran dengan menerapkan bahan ajar berupa aplikasi Augmented Reality dalam pengenalan bahasa isyarat di sekolah.

Target yang akan dihasilkan dari kegiatan Pengabdian Kepada Masyarakat ini adalah sebagai berikut:

1. Peningkatan kompetensi penguasaan ilmu pengetahuan dan teknologi informasi bagi pihak sekolah, guru dan siswa dalam bidang teknologi Augmented Reality

2. Penyuluhan dan pelatihan yang dilaksanakan akan memberikan dampak yang sangat baik terhadap proses pembelajaran di SLB Negeri Luragung 
3. Target lainnya yang diharapakan bagi tim pengusul ini adalah sebagai bentuk pelaksanaan Tri Dharma Perguruan Tinggi dan sebagai bentuk rasa kepedulian kepada pemberdayaan masyarakat.

Mengacu pada kegiatan pengabdian kepada masyarakat ini, maka manfaat yang dapat diperoleh adalah sebagai berikut:

1. Dapat menerapkan dan menggunakan aplikasi Augmented Reality Pengenalan Bahasa Isyarat pada smartphone dengan mudah dan menarik sebagai media pembelajaran tambahan.

2. Dapat meningkatkan pemahaman dalam penggunaan aplikasi Augmented Reality Pengenalan Bahasa Isyarat dalam proses pembelajaran di SLB Negeri Luragung Pemahaman yang dimaksud meliputi:

a. Pemahaman instalasi aplikasi

b. Pemahaman penggunaan aplikasi

c. Pemahaman implementasi aplikasi

3. Dapat meningkatkan kemampuan dalam penggunaan aplikasi Augmented Reality Pengenalan Bahasa Isyarat dalam proses pembelajaran di SLB Negeri Luragung, kemampuan yang dimaksud meliputi:

a. Kemampuan instalasi aplikasi

b. Kemampuan penggunaan aplikasi

c. Kemampuan implementasi aplikasi

Dampak sosial yang terlihat dari adanya kegiatan pengabdian kepada masyarakat ini adalah sebagai berikut:

1. Terbukanya wawasan dan pola pikir Guru dan siswa dalam penggunan teknologi Augmented Reality

2. Peningkatan kompetensi penguasaan ilmu pengetahuan dan teknologi informasi bagi pihak sekolah, guru dan siswa dalam bidang teknologi Augmented Reality

3. Penyuluhan dan pelatihan yang dilaksanakan akan memberikan dampak yang sangat baik terhadap proses pembelajaran di SLB Negeri Luragung

4. Target lainnya yang diharapakan bagi tim pengusul ini adalah sebagai bentuk pelaksanaan Tri Dharma Perguruan Tinggi dan sebagai bentuk rasa kepedulian kepada pemberdayaan masyarakat.

5. Proses pembelajaran menjadi menarik dan interaktif

\section{METODE PELAKSANAAN}

Kegiatan Pengabdian Pada Masyarakat ini berupa pelatihan dan penerapan aplikasi Augmented Reality Pengenalan Bahasa Isyarat. Setelah diberikan pelatihan, selanjutnya mereka dibimbing untuk menerapkan hasil pelatihan dalam rangka meningkatkan kemampuan penggunaan teknologi Augmented Reality dalam proses pembelajaran di SLB Negeri Luragung.

Berikut ini adalah tahapan pelatihan yang akan dilakukan: 
1. Tahap Persiapan, Tahap persiapan yang dilakukan meliputi:

a. Survey

b. Pemantapan dan penetuan lokasi dan sasaran

c. Penyusunan bahan/materi pelatihan, yang meliputi: makalah/modul untuk kegiatan pelatihan "Pelatihan Penerapan Aplikasi Augmented Reality Pengenalan Bahasa Isyarat DI SLB Negeri Luragung Desa Cirahayu Kecamatan Luragung Kabupaten Kuningan Provinsi Jawa Barat".

\section{Tahap Pelaksanaan Pelatihan}

Dalam tahap ini dilakukan beberapa tahapan; pertama, penjelasan tentang pentingnya pemanfaatan media pembelajaran alternative berbasis teknologi augmented reality.

Pemberian kemampuan ini dilakukan dengan teknik simulasi agar para peserta mendapatkan pengalaman langsung sekaligus pengayaan dari teman-teman sebayanya dan dari tim pemateri.

3. Metode Pelatihan, untuk melaksanakan kegiatan tersebut digunakan beberapa metode pelatihan, yaitu:

a. Metode Ceramah, Metode ceramah dipilih untuk memberikan penjelasan tentang tata cara instalasi dan penggunaan aplikasi Augmented Reality untuk pengenalan bahasa isyarat berbasis android.

b. Metode Tanya Jawab, Metode tanya jawab sangat penting bagi para peserta pelatihan, baik di saat menerima penjelasan tema pelatihan maupun saat mempraktekkannya, Metode ini memungkinkan peseta menggali pengetahuan sebanyak-banyaknya tentang penggunaan aplikasi Augmented Reality untuk pengenalan bahasa isyarat berbasis android.

c. Metode Simulasi, Metode simulasi ini dilakukan untuk memberikan kesempatan kepada para peserta pelatihan untuk mempraktekan materi pelatihan yang diperoleh. Harapannya, peserta pelatihan akan benar-benar menguasai materi pelatihan yang diterima, mengetahui tingkat kemampuannya dalam menerapkan penggunaan aplikasi Augmented Reality untuk pengenalan bahasa isyarat berbasis android. dalam pembelajaran dan pengelolaan kelembagaan secara tehnis dan kemudian mengidentifikasi kesulitan-kesulitan (jika masih ada) untuk kemudian dipecahkan atau ditemukan solusinya.

\section{HASIL DAN PEMBAHASAN}

Kegiatan Pengabdian Kepada Masyarakat di SLB Negeri Luragung dengan tema "Pelatihan Penerapan Aplikasi Augmented Reality Pengenalan Bahasa Isyarat DI SLB Negeri Luragung Desa Cirahayu Kecamatan Luragung Kabupaten Kuningan Provinsi Jawa Barat" dapat dilaksanakan sesuai dengan metode dan rencana yang telah ditetapkan. 


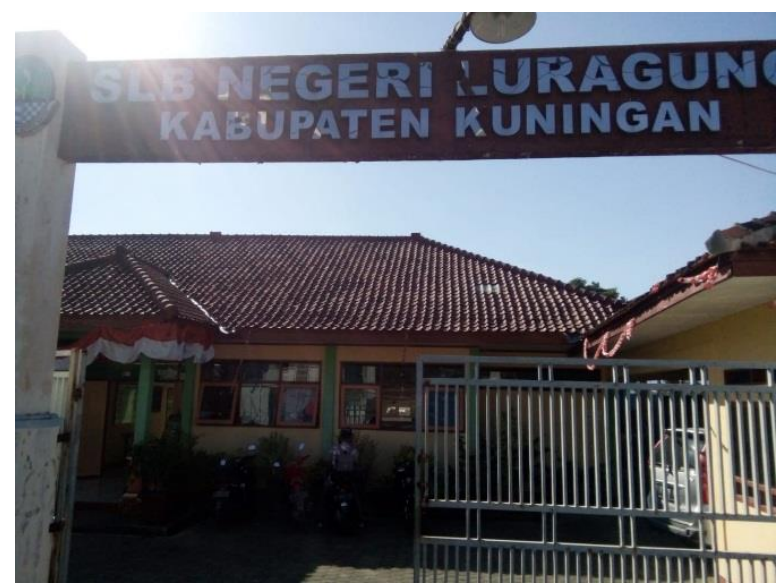

Gb.01. SLB Negeri Luragung tempat pengabdian kepada masyarakat

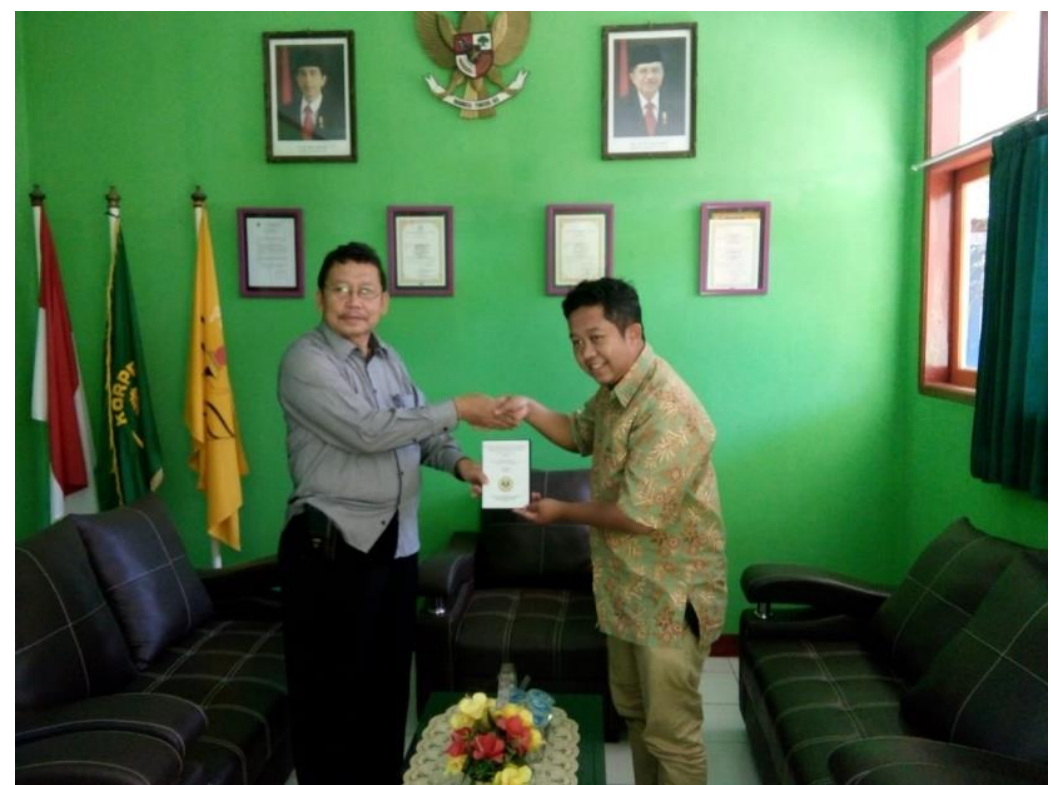

Gb.02. Kegiatan Penyerahan Aplikasi Augmented Reality kepada Kepala Sekolah

Peserta yang terdiri dari Guru dan siswa dapat mengikuti kegiatan dari awal sampai dengan selesai dengan baik dan tertib. Para peserta terlihat yang tertarik, semangat dan antusias menyimak materi yang dipresentasikan oleh tim Pengabdian Kepada Masyarakat. Metode tanya jawab menjadi metode yang menarik dalam sesi kegiatan pengabdian ini, dikarenakan banyak peserta yang bertanya. Selain metode tanya jawab metode simulasi aplikasi langsung juga sangat menarik dikarenakan peserta dapat mencoba langsung aplikasi yang dibangun untuk membantu proses pembelajaran di SLB Negeri Luragung. 


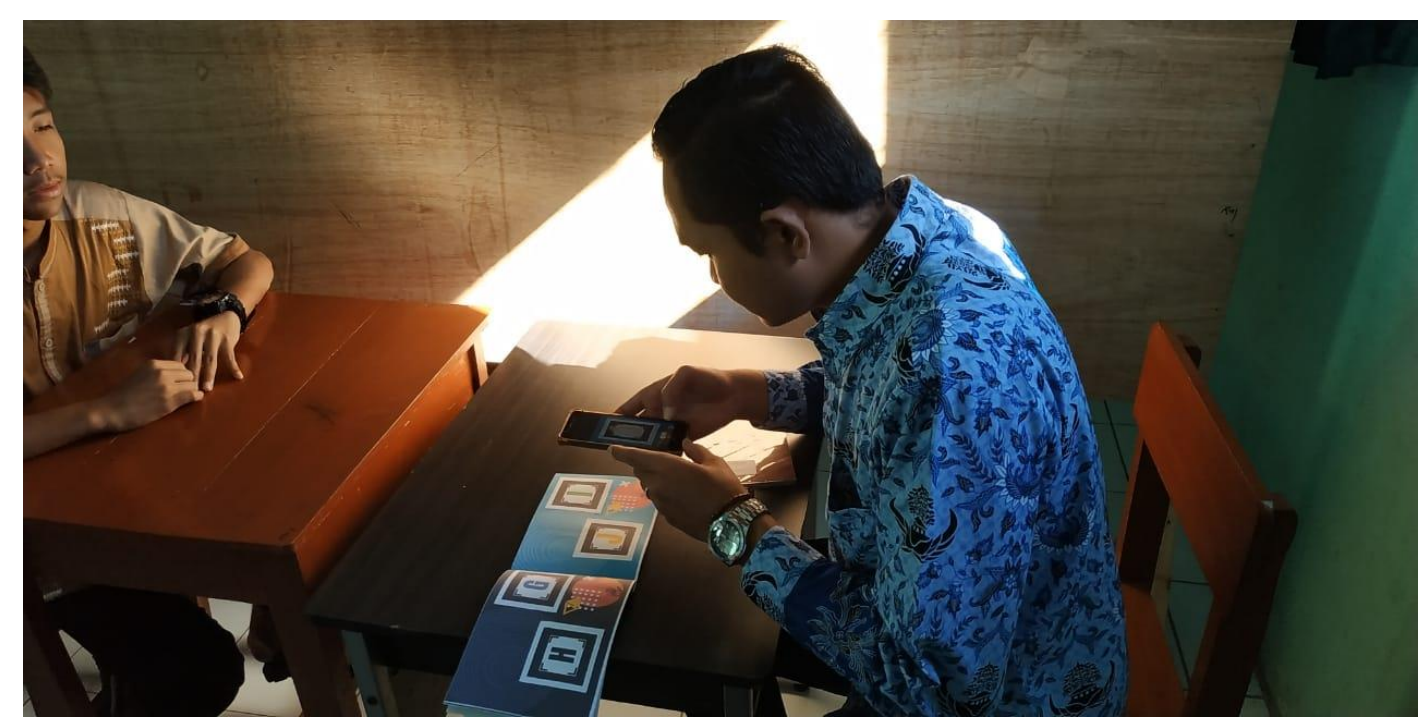

Gb.03. Kegiatan simulasi aplikasi Augmented Reality kepada Guru
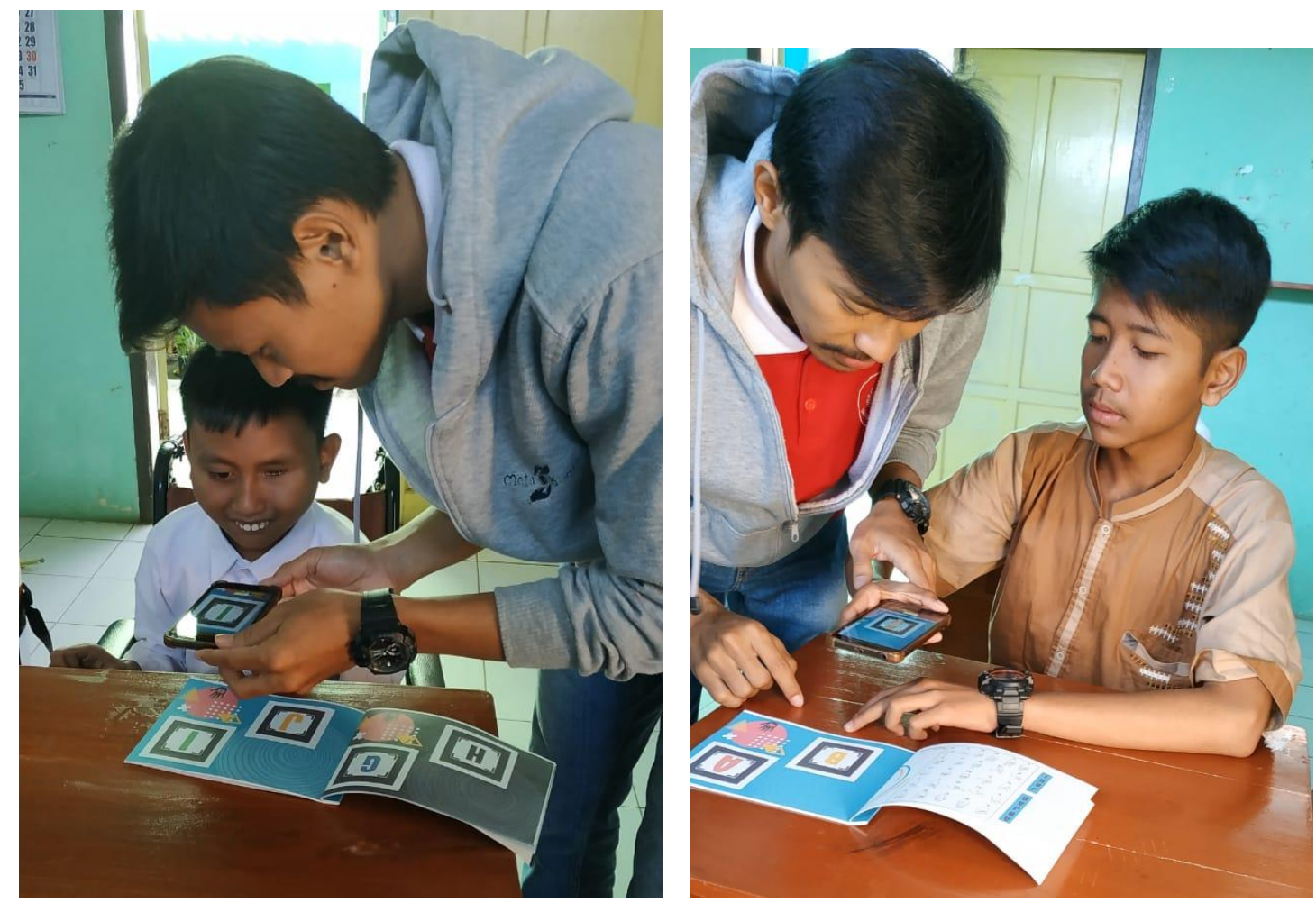

Gb.04. Kegiatan simulasi aplikasi Augmented Reality kepada siswa dibantu mahasiswa

Kegiatan pelatihan dilakukan melalui kegiatan ceramah, tanya jawab, dan kegiatan simulasi. Kegiatan ceramah berisi tentang pemaparan tentang manfaat dan penggunaan dari aplikasi Augmented Reality untuk pengenalan bahasa isyarat. Kegiatan ceramah bertujuan untuk memberikan pemahaman, pengetahuan dan gambaran mengenai maanfaat dan tata cara penggunaan aplikasi. 
Setelah kegiatan ceramah dilanjutkan dengan kegiatan tanya jawab. Pada kegiatan tanya jawab para peserta bertanya mengenai banyak hal mengenai penggunaan aplikasi augmneted reality pengenalan bahasa isyarat. Setiap pertanyaan yang ditanyakan peserta dapat dijawab dan dijelaskan dengan baik. Sehingga pemahaman peserta menjadi bertambah. Kegiatan terakhir yaitu kegiatan simulasi. Pada kegiatan simulasi peserta yang terdiri dari Guru dan siswa mencoba langsung aplikasi Augmented Reality pengenalan bahasa isyarat. Dari hasil percobaan didapatkan antusiasme yang tinggi dari semua peserta yang mencoba menggunakan aplikasi augmented reality.

\section{SIMPULAN}

Hasil yang didapatkan dari kegiatan pengabdian kepada masyarakat di SLB Negeri Luragung adalah sebagai berikut:

1. Meningkatnya kompetensi penguasaan ilmu pengetahuan dan teknologi informasi bagi Guru dan siswa dalam bidang teknologi augmented reality.

2. Meningkatnya kemampuan dalam penggunaan media bahan ajar alternative atau bahan ajar tambahan berupa penerapan aplikasi augmented reality dalam pengenalan bahasa isyarat.

3. Pelatihan dapat memberikan stimulus untuk proses pembelajaran dengan menerapkan bahan ajar berupa aplikasi augmented reality dalam pengenalan bahasa isyarat di sekolah.

4. Pelatihan dapat berjalan dengan baik dan mendapat dukungan dari pihak sekolah.

\section{SARAN}

Saran dari kegiatan pengabdian kepada masyarakat ini adalah sebagai berikut:

1. Semoga kegiatan pengabdian kepada masyarakat ini bisa dilakukan secara terus menerus dan dilokasi yang berbeda.

2. Semoga sarana dan prasarana yang ada dapat ditambah untuk menunjang kegiatan pengabdian kepada masyarakat ini.

\section{UCAPAN TERIMA KASIH}

Penulis ucapkan terima kasih kepada semua pihak yang telah membantu terlaksananya kegiatan pengabdian kepada masyarakat di SLB Negeri Luragung, diantaranya adalah Rektor Universitas Kuningan, Ketua LPPM Universitas Kuningan, Dekan Fakultas Ilmu Komputer, Kepala Sekolah SLB Negeri Luragung, Bapak/Ibu Guru di SLB Negeri Luragung, Seluruh siswa di SLB Negeri Luragung. Semoga dengan adanya kegiatan pengabdian kepada masyarakat ini dapat berjalan berkesinambungan dan diterima banyak pihak. 


\section{DAFTAR PUSTAKA}

Hardiyanti, Margareta., Umi Lalili, dan Abdul Munif. 2013. Rancang Bangun Aplikasi Pembelajaran Pengucapan Bagi Penderita Tunarungu Menggunakan Teknologi Kinect. Jurnal Teknik POMITS Vol.2, No.01. Surabaya.

Indras ,Dhoni., Herman Tolle, dan Agi Putra. 2018. Perancangan Aplikasi Communication Board Berbasis Android Tablet Sebagai Media Pembelajaran dan Komunikasi Bagi Anak Tuna Rungu”. Jurnal PengembanganTeknologi Informasi dan Ilmu Komputer Vol 2 No.08. Surabaya.

Mutia, Aisyah., Husni Thamrin, dan Umi Fadlilah. 2013. Aplikasi Multimedia Bahasa Isyarat Dasar Anak Tuna Rungu 6-9 Tahun”. Skripsi Program Studi Teknik Informatika Fakultas Komunikasi dan Informatika Universitas Muhammadiyah Surakarta, tidak diterbitkan,. Surakarta.

Suwari Akhmaddhian dan Erga Yuhandra. 2018. Bantuan Hukum Bagi Tenaga Pendidik Dan Kependidikan Di Desa Mancagar Kabupaten Kuningan, Indonesia. Empowerment : Jurnal Pengabdian Masyarakat, e-ISSN 2598-2052 Vol. 01 Nomor 01. 2018.72-78.

Tito Sugiharto. 2016. Rancang Bangun Pengembangan Aplikasi Pembelajaran Bahasa Inggris Berbasis Multimedia Interaktif. JEJARING: Jurnal Teknologi dan Manajemen Informatika. Vol.01. No.01 Tahun 2016.

Qoyyimah, Amanda Dina dan Eka Pramono. 2017. Aplikasi Permainan Berbasis Android dalam Meningkatkan Kemampuan Kosakata Anak Tuna Rungu. Jurnal Ortopedagogia Volume 3, No.02. Malang. 